\title{
PRENESENI DJELOKRUG U LOKALNOJ SAMOUPRAVI: TEORIJSKA RAZMATRANJA I KOMPARATIVNA ISKUSTVA
}

Sažetak: $\quad$ Ukidanjem ureda državne uprave u siječnju 2020., poslovi koje su obavljali uredi kao prvostupanjska tijela državne uprave povjereni su na obavljanje županijama u njihov preneseni djelokrug čime je model dekoncentriranog obavljanja poslova državne uprave u Hrvatskoj zamijenjen modelom upravne decentralizacije. Uradu se stoga prikazuju obilježja prenesenog djelokruga kao modela organizacije obavljanja poslova državne uprave u teritorijalnim jedinicama te upravne decentralizacije čiji je preneseni djelokrug institucijski rezultat. Pregled znanstvene literature o prenesenom djelokrugu i efektima provodenja upravne decentralizacije dopunjen je komparativnim prikazom efekata primjene prenesenog djelokruga u češkoj $i$ njemačkoj lokalnoj samoupravi. Na temelju teorijskih razmatranja i komparativnih iskustava, raspravlja se o mogućim učincima primjene prenesenog djelokruga $u$ hrvatskim županijama na njihov institucionalni razvoj i obavljanje prenesenih poslova.

Ključne riječi: preneseni djelokrug, upravna decentralizacija, efekti upravne decentralizacije, češka i njemačka lokalna samouprava, ukidanje ureda državne uprave, hrvatske županije

\section{UVOD}

Preneseni djelokrug varijanta je organizacije obavljanja poslova državne uprave u teritorijalnim jedinicama u kojoj poslove državne uprave za državnu vlast obavljaju jedinice lokalne samouprave. Institucijski je rezultat procesa upravne decentralizacije kojim državna vlast na lokalne jedinice prenosi izvršavanje poslova državne uprave zadržavajući pritom ovlasti regu-

Dr. sc. Iva Lopižić, poslijedoktorandica Pravnog fakulteta Sveučilišta u Zagrebu, Trg Republike Hrvatske 14, 10000 Zagreb. E-adresa: iva.lopizic@pravo.hr. ORCID: https://orcid.org/0000-0002-1157-0602. 
lacije i intenzivnog nadzora nad prenesenim poslovima te financijski teret i odgovornost za njihovo obavljanje. ${ }^{1}$ Tema decentralizacije posljednjih je desetljeća neizostavna u znanstvenim i praktičnim raspravama o organizaciji javne uprave i obavljanju javnih poslova te odnosima između različitih razina javne vlasti diljem svijeta. ${ }^{2}$ Međutim, rasprave vezane uz teritorijalnu decentralizaciju pretežito se odnose na politički oblik teritorijalne decentralizacije kojom nastaje lokalna samouprava kao protuteža središnjoj državnoj vlasti odnosno kojom se širi krug javnih poslova o kojima lokalne jedinice samostalno odlučuju, ${ }^{3}$ dok je tema upravne decentralizacije u većoj mjeri zanemarena. Razlog tome je okolnost da su koncept upravne decentralizacije i organizacija obavljanja poslova državne uprave u modelu prenesenog djelokruga specifični za germansku upravnu doktrinu i tradiciju pa je teorijska rasprava o ovim pojavama usko vezana uz upravnu i političku znanost zemalja tog upravnog kruga. ${ }^{4}$ Teme prenesenog djelokruga i upravne decentralizacije ukidanjem ureda državne uprave 2020. postale su od većeg značaja za hrvatsku javnu upravu. Donošenjem novog Zakona o sustavu državne uprave, ${ }^{5}$ ukinuti su uredi državne uprave kao prvostupanjska tijela državne uprave, a njihovi poslovi povjereni su na obavljanje županijama u njihov preneseni djelokrug. Ovom organizacijskom promjenom koja predstavlja upravnu decentralizaciju, županije su preuzele obavljanje oko 60 poslova državne uprave ${ }^{6}$ te oko 2.000 službenika ureda čime se broj zaposlenih u županijskoj upravi gotovo udvostručio. ${ }^{7}$ Model dekoncentriranog obavljanja poslova državne uprave ovom je organizacijskom promjenom zamijenjen modelom upravne decentralizacije koji je dotad bio primijenjen jedino za obavljanje poslova državne uprave u Gradu Zagrebu.

Cilj je ovog rada sistematizirati i nadograditi teorijsku spoznaju o prenesenom djelokrugu i upravnoj decentralizaciji te formulirati pretpostavke o tome kako će širenje prenesenog djelokruga županija utjecati na njihov institucionalni položaj i obavljanje prenesenih poslova. U radu se prvo daje pregled znanstvene literature o karakteristikama prenesenog djelokruga i teorijskih predviđanja o učincima upravne decentralizacije na razvoj sustava lokalne samouprave i obavljanje javnih poslova u teritorijalnim jedinicama. Pregled teorije dopunjen je komparativnim prikazom obavljanja poslova državne uprave u prenesenom djelokrugu u češkim i njemačkim lokalnim jedinicama. Češka i Njemačka jedine su europske zemlje u kojima se većina poslova državne uprave u teritorijalnim jedinicama obavlja u prenesenom djelokrugu. U Češkoj je ovaj model primijenjen od 2003. kad su ukinuti okružni uredi kao prvostupanjska tijela državne uprave, a njihovi poslovi preneseni općinama i novoosnovanim regijama. Preneseni djelokrug dio je njemačke upravne tradicije koja počiva na multifunkcionalnom načelu koje zahtijeva da teritorijalne jedinice budu zadužene za obavljanje što šireg kruga javnih poslova. Postaje sve zna-

1 Ivan Koprić i drugi, Upravna znanost - javna uprava u suvremenom europskom kontekstu (Pravni fakultet i Studijski centar za javnu upravu i javne financije 2014) 280, 314

2 Vidi Christopher Pollit, 'Decentralization: A Central Concept in Contemporary Public Management' in Ewan Ferlie, Laurence E Lynn and Christopher Pollitt (eds), The Oxford Handbook of Public Management (OUP 2008) 371-97.

3 Koprić i drugi (n 1) 314.

4 Ivan Koprić, 'Lokalni poslovi hrvatskih županija u svjetlu različitih europskih tradicija' u Eugen Pusić i drugi (ed), Hrestomatija upravne znanosti, vol 2 (Pravni fakultet u Zagrebu 1998) 153-156.

5 Zakon o sustavu državne uprave (NN 69/2019) (HR), dalje: ZSDU.

6 Iva Lopižić, 'Uloga ureda državne uprave u hrvatskome upravno-političkom sustavu’ (2020) 20(3) Hrvatska i komparativna javna uprava 563.

7 U županijama je 2018. bilo 2.276 zaposlenih (Ministarstvo financija, 'Financijski izvještaji JLP(R)S' (Ministarstvo financija, 2020) <https://mfin.gov.hr/istaknute-teme/lokalna-samouprava/financijski-izvjestaji-jlp-r-s/203〉 pristupljeno 2. studenog 2021. 
čajnija organizacijska varijanta sredinom 2000-ih kad sve veći broj saveznih zemalja ukida svoje područne jedinice i prenosi poslove državne uprave okruzima i gradovima sa statusom okruga. Komparacija češkog i njemačkog slučaja pogodna je za razvoj teorije o prenesenom djelokrugu jer se uspoređuju vrlo različiti sustavi lokalne samouprave pri čemu je Češka prototip zemlje sa slabo razvijenom, a Njemačka zemlje sa snažno razvijenom lokalnom samoupravom. ${ }^{8}$

U radu se potom identificiraju pozitivni i negativni efekti primjene prenesenog djelokruga u češkoj i njemačkoj lokalnoj samoupravi te faktori koji utječu na ostvarivanje teorijskih predviđanja o učincima upravne decentralizacije. Na temelju pregleda znanstvene literature o prenesenom djelokrugu i efektima upravne decentralizacije te čeških i njemačkih iskustava, a uzimajući u obzir hrvatske specifičnosti, formuliraju se određene pretpostavke o utjecaju povjeravanja poslova državne uprave županijama na institucionalni razvoj županija i obavljanje poslova državne uprave u režimu prenesenog djelokruga.

\section{PRENESENI DJELOKRUG I UPRAVNA DECENTRALIZACIJA: TEORIJSKA RAZMATRANJA}

Preneseni djelokrug varijanta je organizacije obavljanja poslova državne uprave u teritorijalnim jedinicama. ${ }^{9} \mathrm{U}$ ovom modelu, poslove državne uprave obavljaju lokalne samoupravne jedinice koje se javljaju kao nositeljice dviju skupina poslova: vlastitih, lokalnih poslova koje obavljaju u samoupravnom djelokrugu kada imaju određenu razinu autonomije u odnosu na državnu vlast, i prenesenih, državnih poslova (übertragen) koje obavljaju u prenesenom djelokrugu kada je njihova autonomija sužena, a status približen statusu državnih tijela. Model prenesenog djelokruga naziva se još i dvojnim, ${ }^{10}$ odnosno kombiniranim ${ }^{11}$ modelom. Razvio se u Francuskoj za vrijeme Revolucije da bi se preko Belgije proširio na Njemačku, a onda i zemlje koje su upravni sustav razvijale pod germanskim utjecajem. Na taj je način preneseni djelokrug prihvaćen u hrvatskim krajevima i postao dio hrvatske upravne tradicije. ${ }^{12}$

Sužena autonomija lokalnih jedinica kada poslove obavljaju u prenesenom djelokrugu očituje se prije svega u njihovim regulacijskim ovlastima. Dok o poslovima iz samoupravnog djelokruga lokalne jedinice odlučuju samostalno, ovlast reguliranja poslova iz prenesenog djelokruga pridržana je središnjoj državnoj vlasti. Posljedica ovakve distribucije regulativnih ovlasti različiti je intenzitet državnog nadzora nad lokalnim jedinicama pri obavljanju poslova iz samoupravnog i prenesenog djelokruga. Obavljajući poslove iz samoupravnog djelokruga, lokalne jedinice podložne su nadzoru ustavnosti i zakonitosti, a obavljajući poslove u prene-

8 Goranka Lalić Novak, 'Komparativna metoda u proučavanju javne uprave: potencijali i problemi' (2015) 15(1) Hrvatska i komparativna javna uprava 20-21.

9 Iva Lopižić, 'Modeli dekoncentriranog obavljanja poslova državne uprave u postsocijalističkim zemljama' (2017) 17(1) Hrvatska i komparativna javna uprava 81-106.

10 Phillip J Bryson, "'State administration" vs. self-government in the Slovak and Czech Republic' (2008) 41(3) Communist and Post-Communist Studies 343.

11 Jan Hladík J and Václav Kopecký, Public Administration Reform in the Czech Republic: Research Paper 3/2013 (Association for International Affairs 2013) 6 〈https://www.amo.cz/wp-content/uploads/2015/11/amocz-RP-2013-3.pdf> pristupljeno 2. studenog 2021. 
senom djelokrugu i svrhovitosti obavljanja posla. Obavljanje poslova u samoupravnom, odnosno prenesenom djelokrugu razlikuju se još u odgovornosti i financiranju. Za poslove iz samoupravnog djelokruga odgovornost snose same jedinice, dok je odgovornost kod prenesenih poslova i dalje na središnjoj državnoj vlasti. Obavljanje poslova iz samoupravnog djelokruga financiraju same jedinice, a preneseni djelokrug financira središnja vlast. ${ }^{13}$

Tri su temeljne pravne tehnike prenošenja poslova u preneseni djelokrug: zakon, upravni ugovor središnje države sa svakom pojedinom lokalnom jedinicom o uvjetima obavljanja poslova državne uprave te sporazum koji potpisuju središnja vlast s jedne te jedna ili više udruga lokalnih jedinica s druge strane. ${ }^{14} \mathrm{U}$ prvom slučaju, riječ je o obveznom prenesenom djelokrugu dok je u druga dva slučaja riječ o fakultativnom prenesenom djelokrugu karakterističnom za poljske lokalne jedinice. ${ }^{15} \mathrm{U}$ preneseni djelokrug prenose se najčešće poslovi registriranja činjenica rođenja, sklapanja braka i smrti te vođenje evidencija o tim činjenicama, statistički poslovi, poslovi izdavanja identifikacijskih iskaznica i vozačkih dozvola, nadzor gradnje, vojne evidencije i provedba izbora. ${ }^{16}$

Preneseni djelokrug institucijski je rezultat procesa upravne decentralizacije. U njemačkoj upravno-pravnoj tradiciji upravna decentralizacija naziva se lažnom, polovičnom decentralizacijom (unechte Kommunalisierung), za razliku od političke decentralizacije kojom se označava prijenos poslova u samoupravni djelokrug lokalnih jedinica koja je prava, potpuna decentralizacija (echte Kommunalisierung) jer njom lokalne jedinice stječu pravo samostalnog odlučivanja o dodijeljenim javnim poslovima. ${ }^{17}$ Teorija stoga upućuje da provođenje upravne decentralizacije u manjoj mjeri utječe na modifikaciju odnosa državne i lokalne vlasti te da su efekti njezina provođenja blaži od efekata političke decentralizacije. ${ }^{18}$ Efekti provođenja upravne decentralizacije i širenja prenesenog djelokruga mogu se promatrati u odnosu na razvoj i ulogu sustava lokalne samouprave (institucionalni efekti) te u odnosu na obavljanje javnih poslova u teritorijalnim jedinicama (tzv. performance efekti).

Širenje prenesenog djelokruga utječe na razvoj i ulogu lokalne samouprave u tri smjera: jača teritorijalno i multifunkcionalno načelo u organizaciji obavljanja javnih poslova, jača ulogu izvršnog tijela u odnosu na predstavničko tijelo te jača upravnu ulogu lokalnih jedinica. Jačanje teritorijalnog i multifunkcionalnog načela znači da se sve širi krug javnih poslova obavlja u okviru određene lokalne jedinice, a da se osnivanje organizacijskih jedinica zaduženih za obavljanje užeg kruga zadataka javlja kao iznimka. ${ }^{19}$ Širenjem prenesenog djelokruga jača uloga izvršnog čelnika u lokalnim jedinicama koji usmjerava, nadzire i kontrolira lokalni upravni aparat koji izvršava prenesene poslove, a u odnosu na koje predstavnička tijela nemaju nikakve

13 Koprić i drugi (n 1) 280.

14 Ibid 281.

15 Adam Sauer, The System of Local Self-Governments in Poland: Research Paper 6/2013 (Association for International Affairs 2013) 11 <https://www.amo.cz/wp-content/uploads/2015/11/amocz-RP-2013-6.pdf> pristupljeno 2. studenog 2021.

16 Koprić i drugi (n 1) 281.

17 Sabine Kuhlmann and Helmut Wollmann, Introduction to Comparative Public Administration: Administrative Systems and Reforms in Europe (Edward Elgar 2019) 161-63.

18 Renate Reiter and others, 'Impacts of Decentralization: The French Experience in a Comparative Perspective' (2010) 8(2) French Politics 172.

19 Helmut Wollmann, Comparing Local Government Reforms in England, Sweden, France and Germany: Between Continuity and Change, Divergence And Convergence (Wüstenrot Stiftung 2008) 15-16. 
formalne ovlasti. ${ }^{20}$ Jačanje upravne uloge lokalnih jedinica znači da lokalne jedinice lokalnom stanovništvu pružaju sve širi krug javnih usluga, ali uz skučenu političko-interesnu autonomiju i pojačan nadzor državne vlasti pri obavljanju tih poslova. ${ }^{21}$

Efekti koje upravna decentralizacija ima na obavljanje javnih poslova evaluiraju se kroz ulaznu, procesnu i izlaznu dimenziju. Klasifikacija je preuzeta iz literature o mjerenju učinkovitosti upravnih organizacija i prilagođena mjerenju učinaka procesa decentralizacije. ${ }^{22} \mathrm{U}$ odnosu na ulaznu dimenziju, upravna decentralizacija bi u samo manjoj mjeri trebala povećati demokratičnost, transparentnost i odgovornosti u lokalnom upravljanju te omogućiti tek nešto veći utjecaj građana i interesnih skupina na rješavanje javnih problema. U odnosu na procesnu dimenziju, upravna decentralizacija bi trebala imati dvojak učinak. Trebala bi ojačati koordinaciju i suradnju unutar lokalne jedinice koja je preuzela poslove te tako omogućiti nešto integriraniji pristup rješavanju javnih problema. No provođenje upravne decentralizacije trebalo bi u nekoj mjeri oslabiti i otežati vertikalnu koordinaciju i kontrolu državne vlasti nad obavljanjem poslova. U odnosu na izlaznu dimenziju, provođenje upravne decentralizacije trebalo bi dovesti do povećanja neujednačenosti usluga među lokalnim jedinicama zbog razlike u njihovim kapacitetima. Mogu se očekivati i nešto veća ekonomičnost, ali i smanjenje kvalitete i efektivnosti usluga zbog smanjenja specijalizacije i većeg političkog utjecaja na rješavanje u upravim stvarima. ${ }^{23}$

U znanstvenoj literaturi kao preduvjet uspješne primjene modela prenesenog djelokruga i provođenja upravne decentralizacije navodi se kapacitet lokalnih jedinica za obavljanje javnih poslova. U prvom redu riječ je o financijskom kapacitetu, ali i racionalnoj organizaciji te efikasnom i profesionalnom osoblju lokalne samouprave. Izostanu li neke od ovih pretpostavki, preneseni djelokrug može predstavljati uteg lokalnim jedinicama, gušiti lokalnu autonomiju, dovesti do etatizacije lokalne samouprave te imati negativne učinke na obavljanje poslova i iz samoupravnog i iz prenesenog djelokruga. ${ }^{24}$

\section{EUROPSKA ISKUSTVA S UPRAVNOM DECENTRALIZACIJOM: PRENESENI DJELOKRUG U ČEŠKOJ I NJEMAČKOJ LOKALNOJ SAMOUPRAVI}

\section{1. ČEŠKA}

Organizacija obavljanja javnih poslova na teritoriju. Od ustavnih izmjena iz 1997., Češka je unitarna država s općinama i regijama kao samoupravnim teritorijalnim jedinicama. Uz op-

20 Helmut Wollmann, 'Reforming Local Leadership and Local Democracy: The Cases of England, Sweden, Germany and France in Comparative Perspective' (2008) 34(2) Local Government Studies 280-81.

21 Ivan Koprić, 'Lokalna samouprava u razvoju: vrijednosti i uloge' (Academia.edu, 2015) 3-4 <https://www.academia. edu/21588077/ Uloge_lokalne_samouprave> pristupljeno 2. studenog 2021.

22 Sabine Kuhlmann and Helmut Wollmann, 'The Evaluation of Institutional Reforms at Sub-national Government Levels: A Still Neglected Research Agenda' (2011) 37(5) Local Government Studies 479-494.

23 Reiter (n 18) 172, 174; Sabine Kuhlmann and Ellen Wayenberg, 'Institutional Impact Assessment in Multi-Level Systems: Conceptualizing Decentralization Effects from a Comparative Perspective' (2016) 82(2) International Review of Administrative Sciences 233-54. 
ćine i regije, teritorijalni sustav Češke obuhvaćao je do 2003. i 77 okruga, upravnih jedinica u kojima su okružni uredi obavljali poslove državne uprave. Ukidanjem okruga, poslovi iz njihova djelokruga preneseni su na općine i regije. Dok je preneseni djelokrug regija jednak, općine se razlikuju s obzirom na širinu prenesenog djelokruga i teritorij za koji obavljaju poslove državne uprave: sve 6.254 općine obavljaju osnovni krug prenesenih poslova (I. tip), a širi krug poslova za okolne općine obavljaju općine s upravnim uredom i to uglavnom: autoriziranim uredom (388) (II. tip) i proširenim uredom (205) (III. tip). ${ }^{25}$ Općine III. tipa pružaju prenesene poslove na području u kojem je oko 52.000 građana. Moguće je da manje općine s općinama III. tipa ugovore obavljanje šireg kruga poslova. Godine 2017. sklopljena su 7.102 takva ugovora. ${ }^{26}$ Dio poslova državne uprave na teritoriju obavljaju područne jedinice ministarstava (npr. uredi za financije i skupljanje poreza, carinski uredi, uprave za socijalnu sigurnost, katastarski uredi, regionalni uredi za higijenu itd.). ${ }^{27}$

Provedene reforme. Ukidanjem okružnih ureda, oko $80 \%$ poslova državne uprave preneseno je na III. tip općina, dok su ostale poslove (one koji zahtijevaju veći stupanj specijalizacije ili širi teritorijalni radijus) preuzele regije, novoosnovane upravne organizacije i ministarstva. ${ }^{28}$ Cilj reforme bilo je "približavanje državne uprave građanima". Procjenjuje se da je ukidanjem okružnih ureda oko 19.000 službenika premješteno u upravna tijela općina i regija. ${ }^{29}$ Prijenos poslova samo na određene općine utjecao je na strukturu poslova općina: I. tip općina opterećen je obavljanjem poslova državne uprave u odnosu na vlastite poslove u omjeru 1:2, II. tip 1:1, a III. tip 2:1. ${ }^{30}$ Procijenjeno je da je svaka prenesena funkcija nosila financijski trošak (plaća zaposlenog i materijalni rashodi) 333,995.69 čeških kruna. Reforma nije bila dovoljno pripremljena, ciljevi reforme nisu bili jasno određeni te se sve do posljednjeg trenutka nije znalo koja će tijela, prema kojem kriteriju i u kojem opsegu preuzeti poslove. ${ }^{31}$

Efekti provedenih reformi. Istraživanja efekata prenošenja poslova državne uprave na lokalne samoupravne jedinice pretežito se odnose na financijske efekte. Prva istraživanja troškova III. tipa općina za obavljanje prenesenih poslova pokazala su da su općine u prvim mjesecima nakon reforme pokrivale čak 50\% troškova obavljanja prenesenog djelokruga. ${ }^{32}$ Preneseni djelokrug češkim općinama predstavlja preveliko opterećenje pa one ne mogu osigurati kvalitetno izvršenje poslova ni iz prenesenog ni iz samoupravnog djelokruga. Općine s jednakim krugom

25 Ministry of Interior, Public Administration in Czech Republic (Ministry of Interior 2018) 11.

26 Ibid 24.

27 Ibid 11.

28 Za pregled prenesenih poslova vidi Lenka Štastná and Martin Gregor, 'Local Government Efficiency: Evidence from Czech Municipalities' (2011) IES Working Paper 14/2011 6 <https://papers.ssrn.com/sol3/papers.cfm?abstract_id=1978730> pristupljeno 2. studenog 2021.

David Špaček and Jarmila Neshybová, 'Brief History and Current Trends of Public Administration Reform in the Czech Republic' (ResearchGate, 2010) 5 <https://www.researchgate.net/publication/228448910_ Brief_history_and_current_trends_of_ public_administration_reform_in_the_Czech_Republic> pristupljeno 2. studenog 2021.

30 Ekonomski institut u Pragu 2009, 22 prema David Špaček and Petra Dvořáková, 'Impact of Economic Crisis on Municipal Budgets in the Czech Republic' (2011) 14(1) European Research Studies 38.

31 Okresní úřady - co bude dál?’ Deník (7. kolovoza 2000) 〈http://www.dvs.cz/clanek.asp?id=59508> pristupljeno 2. studenog 2021.

32 Helena Langšádlová, 'Náklady na výkon přenesené působnosti' Deník (Prague, 9 January 2004)<http://denik.obce.cz/clanek. asp?id=5780899> pristupljeno 2 . studenog 2021. 
poslova troše različita sredstva za njihovo obavljanje ${ }^{33}$ pri čemu država nema uvid kako se sredstva troše jer općine nisu dužne izvještavati državu o troškovima. ${ }^{34}$ Državne naknade za obavljanje prenesenih poslova su nedostatne. Sredstva su najmanje dostatna u općinama koje obavljaju najuži krug prenesenih poslova, a najviše dostatna u općinama III. tipa ${ }^{35}$ što produbljuje jaz u stupnju razvijenosti čeških lokalnih jedinica.

Ukidanje okružnih ureda i premještanje obavljanja poslova u uže teritorijalne jedinice bilo je predmet kritika zbog očekivanog smanjenja efikasnosti prema ekonomiji razmjera. ${ }^{36}$ Svakako, usporedba učinkovitosti slovačkih i čeških općina u području izdavanja građevinskih dozvola pokazala je kako različiti institucionalni aranžmani obavljanja poslova (suradnja lokalnih jedinica v. preneseni djelokrug) nisu generirali statistički značajne razlike u učinkovitosti već da ona ovisi o drugim faktorima. ${ }^{37}$ Půček i Ochrana istraživali su efektivnost potrošnje regija na službenike zadužene za obavljanje poslova prenesenog djelokruga u razdoblju od 2003. do 2009. Došli su do rezultata kako je broj zaposlenih na prenesenim poslovima $20 \%$ veći od potrebnog te kako je broj zaposlenih na ovim poslovima u nekim regijama značajno porastao neovisno o stvarnim potrebama za obavljanje prenesenih poslova. U prosjeku je broj službenika regija rastao za 7\% pri čemu su samo dvije regije smanjile broj zaposlenih na prenesenim poslovima, dok je regija Karlovy Vary bilježila rast zaposlenih od čak $27 \% .{ }^{38} \mathrm{U}$ istom razdoblju regije su $35 \%$ troškova prenesenih funkcija podmirivale iz sredstava predviđenih za financiranje samoupravnog djelokruga. Međutim, analiza je pokazala značajne razlike u sredstvima koje regije troše na prenesene funkcije i mogućnost uštede troškova do čak $25 \%$ sredstava boljim upravljanjem u regijama. ${ }^{39}$

Uz neodrživ model financiranja, obavljanje javnih poslova na teritoriju Češke karakterizira i izrazita neuniformnost. ${ }^{40}$ Kako je reforma provedena u vrlo kratkom roku, lokalne jedinice nisu se stigle pripremiti za obavljanje novih poslova zbog čega je došlo do improvizacije u njihovu obavljanju. ${ }^{41}$ Pri obavljanju prenesenih poslova, lokalne jedinice koordinira nadležno ministarstvo ${ }^{42}$ pa je s obzirom na rast broja subjekata uključenih u obavljanje poslova državne uprave i kompliciranu podjelu nadležnosti vertikalna koordinacija nakon provedene reforme bitno oslabljena. Okružni uredi pružali su tehničku pomoć lokalnim jedinicama, a kako su taj

33 Ministerstvo vnitra České republiky, Analýza aktuálniho stavu veřejné správy (Ministerstvo vnitra, 14. prosinca 2011) 32 <https://www.mvcr.cz/clanek/analyza-aktualniho-stavu-verejne-spravy.aspx> pristupljeno 2. studenog 2021.

36 Peter Hemmings, 'Improving Public-spending Efficiency in Czech Regions and Municipalities' (2006) OECD Economics Department Working Papers, No 49913 <https://doi.org/10.1787/884741503537> pristupljeno 2. studenog 2021.

37 Peter Fandel and others, 'Decentralization Policies in Public Administration in Slovakia and Czech Republic, and Their Impact on Building Offices' Scale Efficiency' (2019) 9(4) Administrative Sciences 1-15

38 Milan Půček and František Ochrana, 'Theory and Practice of Public Sector Savings: The Case of Czech Regions' (2014) 10(2) Transylvanian Review of Administrative Sciences 215

39 Ibid 221.

40 Špaček and Neshybová (n 29) 3.

41 Jana Voldanova, 'From Comparing to Quality Improvement: Benchmarking and Bench-Learning in the Czech Local Government' (16th NISPAcee Annual Conference, May 2008) 3.

42 Richard Pomahač, 'Local Government in the Czech Republic: History, Current Position, Prospective Evolution' in Carlo Panara and Michael R Varney (eds), Local Government in Europe: The 'Fourth Level' in the EU Multi-Layered System of Governance (Routledge 2013) 62. 
posao preuzele regije, općine imaju značajno slabiju mogućnost da dobiju tehničku pomoć (14 regija u odnosu na nekadašnjih 77 okružnih ureda) ${ }^{43}$ na što su se po ukidanju ureda žalili i službenici manjih općina. ${ }^{44}$ Smatra se da je prijenos poslova doveo do etatizacije lokalne samouprave pa se općine III. tipa nazivaju novim slojem dekoncentrirane državne uprave odnosno "malim okruzima". ${ }^{5}$

No, širenje prenesenog djelokruga dovelo je do modernizacije upravljanja u češkim lokalnim jedinicama. Istraživanja su pokazala kako se u III. tipu općina instrumenti za unapređenje kvalitete znatno više koriste nego u općinama I. i II. tipa. ${ }^{46}$ Prenošenje poslova potaknulo je uvođenje benchmarkinga za prenesene poslove koji se kasnije proširio i na poslove iz samoupravnog djelokruga čime se unaprijedilo upravljanje u općinama. ${ }^{47}$ Također, jedinice sa širim prenesenim djelokrugom pioniri su u uvođenju informacijsko-komunikacijske tehnologije u rad lokalnih jedinica. ${ }^{48}$

\subsection{NJEMAČKA}

Organizacija obavljanja javnih poslova na teritoriju. Njemačka je savezna zemlja sastavljena od 13 saveznih zemalja i tri grada koja imaju status saveznih zemalja (Berlin, Hamburg i Bremen). Iako je teritorijalna organizacija u nadležnosti pojedinih zemalja, struktura teritorijalnih jedinica ujednačena je na čitavom državnom teritoriju i najčešće organizirana u dva stupnja: na prvom su općine i gradovi, a drugi stupanj čine okruzi iz čijeg su sastava izuzeti gradovi s više od 100.000 stanovnika. Prema Temeljnom zakonu, savezna vlast ne osniva svoja tijela na razini zemalja i lokalnih jedinica, već su za provedbu federalnog zakonodavstva zadužene zemaljske vlasti. ${ }^{49} \mathrm{U}$ nekim saveznim zemljama organizirani su državni okružni uredi na čelu kojih je predstavnik savezne zemlje zadužen za koordinaciju područnih jedinica koje nisu integrirane u područno upravno tijelo. ${ }^{50}$ Međutim, pretežiti dio poslova zemaljske uprave u Njemačkoj izvršavaju lokalne jedinice u prenesenom djelokrugu. Izvršavajući između 70 i $80 \%$ europskog, saveznog i zemaljskog zakonodavstva, njemačke jedinice imaju najširi djelokrug od svih europskih lokalnih jedinica. ${ }^{51}$

43 David Špaček and Juraj Nemec, Public Administration Characteristics and Performance in EU 28: The Czech Republic (Publications Office of the European Union 2018) 185.

44 Špaček and Neshybová (n 29) 5.

45 Špaček and Nemec (n 43) 182.

46 Špaček and Neshybová (n 29) 14.

47 Voldanova (n 41) 4, 8.

48 David Špaček, 'Trends of E-government in Czech Municipal and Regional Self-Government?' (2012) 12(1) Review of Economic Perpectives 46-47.

49 Romea Manojlović, 'Javna uprava i politički sustav Savezne Republike Njemačke: modernizacija kroz očuvanje tradicije' (2015) 15(1) Hrvatska i komparativna javna uprava 149-50.

50 Gerhard Banner, 'Local Government: A Strategic Resource in German Public Management Reform' in Vincent HoffmannMartinot and Hellmut Wollmann (eds), State and Local Government Reforms in France and Germany: Divergence and Convergence (VS Verlag für Sozialwissenschaften 2006) 135-36. 
Provedene reforme. Integriranje područnih jedinica u lokalnu samoupravu provodi se u njemačkim teritorijalnim jedinicama još od 70-ih godina kao reakciju na proliferaciju područnih jedinica u doba socijalne države. ${ }^{52}$ Ipak, tek početkom 2000-ih provedene su značajnije mjere prenošenja poslova s područnih jedinica na lokalne samoupravne jedinice, od čega je najpoznatiji primjer savezne države Baden-Württemberg. Na prijedlog premijera E. Teufela područne jedinice su 2005. integrirane u lokalne jedinice s ciljevima uštede troškova (država će prve tri godine snositi troškove premještenih službenika nakon čega će svake sljedeće godine za njih izdvajati $3 \%$ manje sredstava čime će se postići uštede do 20\%), smanjivanja birokracije, jačanja lokalne samouprave te integriranog lokalnog upravljanja. Oko 350 od ukupno 450 ekspozitura (s izuzetkom policijskih, poreznih i pravosudnih službi) integrirano je s upravom okruga (35) i gradova sa statusom okruga (4) čime je oko 20.000 državnih službenika počelo raditi u lokalnoj samoupravi. ${ }^{53}$

Efekti provedenih reformi. Reforma ukidanja područnih jedinica u Baden-Württembergu bila je predmet većeg broja znanstvenih istraživanja u kojima su se mjerili efekti upravne decentralizacije određenih vrsta prenesenih poslova (poslovi socijalne zaštite vezani uz prava invalida te inspekcije rada i zaštite okoliša). Istraživanje stavova službenika savezne vlasti i službenika jednog od najbogatijih okruga pokazalo je kako je decentralizacija poslova vezanih uz status invalida ojačala koordinaciju unutar okruga jer su se sve socijalne službe počele obavljati pri istim tijelom te olakšala suradnju s drugim javnim tijelima koja su uključena u provedbu socijalnih politika. Također, omogućila je prilagođavanje upravnog postupanja individualnim potrebama građana (case management). ${ }^{54} \mathrm{U}$ ovom okrugu, decentralizacija je u manjoj mjeri povećala i predstavljenost interesa invalida iz dva razloga - pritiska lokalnih medija na okružne vijećnike i visokih troškova socijalnih usluga koji predstavljaju izazov za okružni proračun. ${ }^{55}$ Međutim, prijenos poslova povećao je neujednačenost usluga koje ovaj okrug pruža u odnosu na druge okruge koji su zauzeli drugačiji pristup u obavljanju poslova pa je povećan pritisak za koordinacijom s ciljem ujednačavanja postupanja prema invalidima, a time i dodatna financijska opterećenja za okrug. ${ }^{56}$

Istraživanja koja su uključila praćenje efekata upravne decentralizacije na druge okruge upućuju na mješovite rezultate. U nekim okruzima nije ojačala horizontalna integracija, povećani su troškovi, a participacija građana, transparentnost i politička odgovornost su, suprotno teorijskim predviđanjima, smanjene. ${ }^{57}$ Istraživanje rješavanja u upravnim stvarima prije i poslije decentralizacije pokazalo je da je tijekom prvih godina porastao broj osnovanih žalbi na odluke lokalnih vlasti o pravima invalida (pri čemu nije uočena politička interferencija u

52 Milan Ramljak, 'Centralna i lokalna uprava u razvoju' u Eugen Pusić i drugi (eds), Hrestomatija upravne znanosti, vol 2 (Pravni fakultet u Zagrebu 1998) 358-61.

53 Banner (n 50) 136.

54 Reiter (n 18) 179

55 Ibid 181.

56 Ibid 179-80.

57 Sabine Kuhlmann, 'Administrative Reforms in Intergovernmental Setting: Impacts on MultiLevel Governance from a Comparative Perspective' in Edoard Ongaro (ed), Multi-Level Governance: The Missing Linkages (Emerald Group Publishing Limited 2015) 200, 206. 
donošenje odluka) što sugerira smanjenje kvalitete odlučivanja, da bi kasnije broj osnovanih žalbi bio na razini njihova broja prije provođenja decentralizacije. ${ }^{58}$

Socijalne službe su 2008. prenesene lokalnim jedinicama i u Sjevernoj Rajni-Vestfaliji i Tiringiji. Prijenos poslova u Sjevernoj Rajni-Vestfaliji doveo je do ušteda, no ne na razini državne procjena njihove visine. Štoviše, neki su okruzi pokrenuli postupke zbog nedovoljnih kompenzacija savezne vlasti za njihovo obavljanje. U jednoj odluci donesenoj po tužbi okruga Tiringije, upravni sud je zaključio "kako upravna decentralizacija povećava troškove zbog raspršenosti upravnog odlučivanja i većeg pritiska građana na administraciju zbog blizine službe". ${ }^{59} \mathrm{U}$ Sjevernoj Rajni-Vestfaliji smanjen je postotak riješenih predmeta u odnosu na broj riješenih predmeta prije decentralizacije, no ujedno je značajno povećan i broj zahtjeva građana što je utjecalo na udio riješenih predmeta. U Tiringiji je također značajno porastao broj zahtjeva građana, ali se uzimajući u obzir i povećanje broja lokalnih službenika zbog decentralizacije procjenjuje da je efikasnost rješavanja u upravnim stvarima smanjena za 6,5\%. ${ }^{60} \mathrm{U}$ Sjevernoj Rajni-Vestfaliji ubrzano je rješavanje u upravnim stvarima, dok se u Tiringiji prosječno trajanje postupka produljilo što upućuje na dodatne, interne faktore koji su od utjecaja na efektivnost u upravnom postupanju. ${ }^{61}$ Prijenos poslova doveo je i do neujednačenosti kvalitete javnih usluga različitih lokalnih jedinica. ${ }^{62}$

Decentralizacija inspekcijskih poslova imala je nešto drugačije učinke. Pokazalo se kako lokalni vijećnici, unatoč svojim uskim ovlastima, uspijevaju ostvariti utjecaj na provođenje nadzora zbog čega su ovlasti i politička odgovornost savezne i lokalne vlasti postale zamućene te se smanjila transparentnost. ${ }^{63}$ Službenici imaju različiti pogled na učinke decentralizacije na horizontalnu integraciju: neki smatraju da je potaknula suradnju među okruzima, dok drugi smatraju da suradnja s drugim okruzima nije potrebna jer teritorijalni radijus obavljanja ovog posla nije od značaja, a da je u samim okruzima povećan konflikt među službenicima. ${ }^{64}$ Svakako, okruzi slabijih kapaciteta nisu u stanju osigurati formalne i neformalne oblike suradnje s drugim okruzima ${ }^{65}$ te je došlo do izrazite neujednačenost u pružanju usluga zbog razlika u političkoj podršci, financijskim resursima i programima usavršavanja službenika različitih jedinica. ${ }^{66}$ Vertikalna integracija je oslabljena jer državni okružni uredi više nemaju kapaciteta da pruže profesionalnu pomoć lokalnim jedinicama. ${ }^{67}$ Smanjena je i kvaliteta obavljanja posla zbog značajnog smanjenja profesionalnog kapaciteta: dok je u područnim jedinicama na ovim

58 Philipp Richter and Sabine Kuhlmann, 'Bessere Leistung mit weniger Ressourcen?: Auswirkungen der Dezentralisierung am Beispiel der Versorgungsverwaltung in Baden-Württemberg' (2010) 3(2) DMS - der moderne staat: Zeitschrift für Public Policy, Recht und Management 410, prema Falk Ebinger and Phillip Richter, 'Decentralizing for performance? A quantitative assessment of functional reforms in the German Lander' (2016) 82(2) International Review of Administrative Science 299.

Ibid 298.

Ibid 298-99.

Ibid 300.

Ibid 300.

Falk Ebinger, Stephan Grohs and Renate Reiter, “The Performance of Decentralization Strategies Compared: An Assessment of Decentralization Strategies and their Impact on Local Government Performance in Germany, France and England' (2011) 37(5) Local Government Studies 561; Kuhlmann (n 57) 206-07.

Kuhlmann (n 57) 204.

Ebinger, Grohs and Reiter (n 63) 563.

Kuhlmann (n 57) 208.

Ibid 205. 
poslovima radilo u prosjeku od 50 do 70 službenika, u lokalnim jedinicama na ovim poslovima radi oko 15 službenika što je dovelo do pada specijalizacije. ${ }^{68}$ Radi uštede troškova nastalih državnim opterećenjem jedinica da snose $20 \%$ ukupnih troškova, u nekim okruzima je zbog financijskih pritisaka daljnje smanjen broj zaposlenih što je rezultiralo daljnjim smanjenjem efektivnosti. ${ }^{69} \mathrm{Na}$ tragu ovih rezultata jesu i nalazi upitnika službenika o percepciji obavljanja prenesenih inspekcijskih poslova koji ukazuju da u odnosu na državne službenike, lokalni službenici u značajnoj mjeri slabije ocjenjuju efikasnost i efektivnost obavljanja inspekcijskih poslova. ${ }^{70}$

\subsection{POUKE ČEŠKOG I NJEMAČKOG SLUČAJA}

Komparativni pregled pokazao je kako je upravna decentralizacija u Češkoj dovela do niza negativnih učinaka kao što su problemi s financiranjem prenesenih poslova i rasipanje javnih sredstava, nepotrebno zapošljavanje novih službenika, otežano obavljanje poslova samoupravnog djelokruga, etatizacija lokalne samouprave, neujednačenost u obavljanju prenesenih poslova te problemi s vertikalnom koordinacijom. Pozitivan učinak prijenosa poslova u češkom slučaju modernizacija je upravljanja općinama. Iskustva njemačkih okruga potvrđuju teorijske pretpostavke o dostatnom kapacitetu lokalnih jedinica kao nužnom preduvjetu za uspješnu upravnu decentralizaciju. U svim okruzima decentralizacija je povećala nejednakost u pružanju usluga građanima te otežala koordinaciju među okruzima. No, prijenos poslova na njemačke okruge s većim kapacitetom doveo je do povećanja integracije unutar okruga, boljeg prilagođavanja pružanja usluga građanima te većeg utjecaja građana na obavljanje poslova, dok je prijenos poslova okruzima slabijeg kapaciteta doveo do povećanja troškova, smanjene transparentnosti u radu okružnih tijela i zamućivanja linije odgovornosti za prenesene poslove, otežane vertikalne koordinacije te smanjene efektivnosti.

Jedina teorijska pretpostavka o učincima upravne decentralizacije koja je potvrđena dostupnim podacima o češkom i njemačkom iskustvu jest ta da upravna decentralizacija povećava neujednačenost usluga među lokalnim jedinicama. Osim kapaciteta lokalnih jedinica, iz komparativnog pregleda proizlazi nekoliko faktora kojima bi se mogla objasniti odstupanja stvarnih učinaka primjene prenesenog djelokruga od teorijskih predviđanja, a koja su u češkom slučaju izraženija nego u njemačkom.

Prvi faktor su karakteristike procesa decentralizacije. Problemi do kojih je dovelo ukidanje okružnih ureda u Češkoj dijelom se objašnjavaju manjkavostima upravljanja decentralizacijom - reforma je provedena u vrlo kratkom roku, bez jasno određenih ciljeva, prethodne procjene mogućih učinaka reforme i utemeljenih odluka kojim jedinicama prenijeti poslove. ${ }^{71}$ Dodatno, tako složena reforma provodila se u kontekstu nestabilnog sustava lokalne samouprave koji je

\footnotetext{
68 Ebinger, Grohs and Reiter (n 63) 570.

69 Kuhlmann (n 57) 202.

70 Ebinger and Richter (n 58) 304-05.

71 Tijekom parlamentarne rasprave pri donošenju zakona, broj općina III. tipa je povećan s 192 na 205, vidi Ministry of Interior, Public Administration in Czech Republic (Ministry of Interior 2004) 12.
} 
bio u procesu izgradnje u kojem su se upravo okružni uredi smatrali najstabilnijim elementom upravljanja na teritoriju Češke. ${ }^{72}$

Drugi faktor su upravna tradicija i primijenjeni model lokalne samouprave. Njemačku upravnu tradiciju karakteriziraju multifunkcionalno načelo i vrijednost političke decentralizacije. Teritorijalnim reformama tijekom 60 -ih do 70 -ih te 90 -ih okruzi su okrupnjeni u jedinice s prosječnim brojem stanovnika od 150 do 200.000 i vrlo širokim djelokrugom. ${ }^{73}$ Istočnonjemačke savezne zemlje vrlo su brzo prošle kroz institucionalnu transformaciju za vrijeme tranzicije i izgradile svoj sustav lokalne samouprave prema uzoru na zapadnonjemačke zemlje. ${ }^{74}$ S druge strane, Češku terete postsocijalističko nasljeđe državnog centralizma te izrazito fragmentirana teritorijalna struktura koja zahtijeva komplicirane institucionalne aranžmane za organizaciju obavljanja prenesenih poslova. ${ }^{75}$

Treći je faktor teritorijalna razina na koju se prenose poslovi i vrsta prenesenih poslova. Prijenos poslova na uže teritorijalne jedinice u Češkoj otežao je vertikalnu koordinaciju zbog povećanja broja jedinica uključenih u obavljanje poslova državne uprave i nemogućnosti regija da nadomjeste okružne urede u ulozi pružanja pomoći lokalnim jedinicama. U Njemačkoj je prijenos visokospecijaliziranih poslova na uže teritorijalne jedinice doveo do smanjenja efikasnosti i ekonomičnosti zbog nemogućnosti osiguranja iste razine profesionalnosti i broja službenika koji obavljaju prenesene poslove.

Kako je njemačka upravna decentralizacija bila predmet istraživanja koja su se replicirala tijekom gotovo desetljeća, pokazalo se kako na učinke decentralizacije utječe i protek vremena. Lokalnim jedinicama upravna decentralizacija može predstavljati šok zbog čega se neposredno nakon prijenosa poslova može smanjiti kvaliteta njihova obavljanja, da bi se kvaliteta obavljanja poslova nakon prilagodbe značajno unaprijedila.

\section{UKIDANJE UREDA DRŽAVNE UPRAVE I PRENESENI DJELOKRUG HRVATSKIH ŽUPANIJA}

Organizacija obavljanja javnih poslova na teritoriju. Hrvatska je administrativno podijeljena na općine (428) i gradove (128) kao jedinice lokalne samouprave i županije (20) kao jedinice područne (regionalne) samouprave. Od 2005. u sustav lokalne samouprave uvedena je kategorija velikih gradova koji uz poslove iz samoupravnog djelokruga grada obavljaju još i poslove održavanja javnih cesta i izdavanja građevinskih i lokacijskih dozvola, drugih akata vezanih uz gradnju te provedbu dokumenata prostornog uređenja, a koji mogu obavljati i poslove iz djelokruga županija. Od 2001., poslove državne uprave na teritoriju obavljali su uredi državne uprave kao prvostupanjska tijela državne uprave (20) koji su nastali integracijom nekadašnjih

72 Špaček and Neshybová (n 29) 5.

73 Wollmann (n 19) 21, 24.

74 Helmut Wollmann, 'Institution Building and Decentralization in Formerly Socialist Countries: The Cases of Poland, Hungary, and East Germany' (1997) 15(4) Environment and Planning C: Politics and Space 463-80.

75 Michal Illner, 'Territorial Decentralization: A Stumbling Block of Democratic Reforms in EastCentral Europe?' (1997) 117 Polish Sociological Review 35. 
županijskih ureda (176) te područne jedinice središnjih tijela državne uprave (njih $1.464 \mathrm{u}$ 2018. godini). ${ }^{76} \mathrm{U}$ Gradu Zagrebu poslove županijskih ureda odnosno ureda državne uprave u prenesenom djelokrugu obavljala su upravna tijela Grada Zagreba.

Decentralizacija poslova ureda državne uprave na županije. Iako su strateški dokumenti razvoja hrvatske javne uprave predviđali jačanje ureda državne uprave kroz integraciju područnih jedinica s uredima, donošenjem novog ZSDU-a 2019. uredi su ukinuti. Pri uredima se obavljalo ukupno 69 poslova, a županije su preuzele sve poslove, osim provođenja upravnog i inspekcijskog nadzora koji su ostali pridržani državnoj upravi. ${ }^{77}$ Poslovi su županijama preneseni izmjenama 61 sektorskog zakona u listopadu 2019., a prijenos poslova i službenika ureda na županije proveden je sporazumima župana i Ministarstva uprave sklopljenih na temelju odluka županijskih skupština. ${ }^{78}$ Županije su primijenile različite modele integracije prenesenih poslova u županijsku upravu: u nekima je primijenjen odvojeni model u kojem upravna tijela obavljaju isključivo poslove samoupravnog ili prenesenog djelokruga, u nekima integrirani model u kojem se poslovi prenesenog i samoupravnog djelokruga obavljaju u okviru istih upravnih odjela, a u nekima mješoviti model u kojima su uz upravne odjele u kojima su spojeni preneseni i samoupravni poslovi organizirani i upravni odjeli koji obavljaju isključivo poslove prenesenog djelokruga. Dio sredstava za obavljanje prenesenih poslova osigurava se u državnom proračunu. ${ }^{79} \mathrm{Za}$ obavljanje prenesenih poslova središnjoj državi odgovara župan, ${ }^{80} \mathrm{a}$ obavljanje poslova u prenesenom djelokrugu nadzire se u upravnom nadzoru. ${ }^{81}$

Mogući efekti primjene prenesenog djelokruga u hrvatskim županijama. Na temelju pregleda znanstvene literature o prenesenom djelokrugu i komparativnih iskustava s upravnom decentralizacijom moguće je formulirati pretpostavke o efektima koje će obavljanje poslova ureda državne uprave u režimu prenesenog djelokruga županija imati na institucionalni razvoj županija i obavljanje prenesenih poslova. Najprije, pretpostavlja se da će na učinke primjene prenesenog djelokruga u nekoj mjeri negativno utjecati karakteristike procesa ukidanja ureda državne uprave i povjeravanja poslova županijama. Kao i u slučaju Češke i dosadašnjih hrvatskih iskustava s provođenjem decentralizacije, ${ }^{82}$ ukidanje ureda državne uprave bilo je nepripremljeno, iznenadno i provedeno u roku od samo nekoliko mjeseci. Županije do posljednjeg trenutka nisu znale koliko službenika će preuzeti, kada će preuzeti poslove i kako će ih financirati. ${ }^{83} \mathrm{Uz}$ probleme koji će proizaći iz nespremnosti županija da preuzmu i obavljaju nove poslove, velik dio problema proizaći će iz neprikladnog režima njihova financiranja. Proračun-

76 Ministarstvo uprave, Strateški plan Ministarstva uprave za razdoblje 2019. - 2021. godine (Ministarstvo uprave, 28. ožujka 2018.) (HR) 4.

77 Lopižić (n 6) 563.

78 Članak 67. ZSDU-a.

79 Članak 23. Zakona o izvršavanju proračuna Republike Hrvatske za 2020. godinu (NN 117/2019, 32/2020, 58/2020, 124/2020) (HR).

80 Članak 35. ZSDU-a.

81 Članak 28. i čl. 29 ZSDU-a.

82 Vidi Ivan Koprić, 'Upravljanje decentralizacijom kao nov pristup razvoju sustava lokalne samouprave’ (2008) 8(1) Hrvatska javna uprava 122-23.

83 Iva Lopižić i Romea Manojlović Toman, 'Prethodna evaluacija ukidanja ureda državne uprave u županijama' (2019) 69(5-6) Zbornik Pravnog fakulteta u Zagrebu 845-46. 
ska ograničenja, dodatno uvjetovana i nadolazećom krizom, bit će velik izazov za osiguranje kvalitete obavljanja prenesenih poslova.

Dalje, hrvatske županije imaju institucionalno nasljeđe integracije državne i lokalne vlasti kroz instituciju župana. Tijekom 90-ih župan je imao dvojnu ulogu: kao predstavnik državne vlasti u županijama i čelnik državnih službi u županijama te kao nositelj izvršne vlasti u županijama i čelnik županijskog upravnog aparata. Iako je aranžman integracije državne i lokalne vlasti sada drugačiji, ovo rješenje može voditi ponovnom tješnjem povezivanju županija s državnom vlasti i ići na štetu uloge županija kao jedinica područne (regionalne) samouprave. Svakako, uloga župana opet bi trebala rasti. Objedinjavanjem obavljanja državnih i županijskih poslova pod okriljem županija, ojačat će multifunkcionalno naličje županija što bi trebalo osnažiti njihov položaj u upravno-političkom sustavu. Također, građanima će na jednom mjestu biti dostupan širi krug javnih usluga. Moguće je da će prijenos poslova u nekoj mjeri i u nekim aspektima potaknuti modernizaciju upravljanja županijama, slično češkom slučaju i slučaju hrvatskih gradova tijekom prijašnjih decentralizacijskih mjera. ${ }^{84}$

Sukladno teoriji o decentralizaciji, obavljanje državnih poslova u prenesenom djelokrugu u Češkoj i Njemačkoj dovelo je do neujednačenosti kvalitete usluga među lokalnim jedinicama. Uzimajući u obzir izrazite razlike između kapaciteta i organizacije hrvatskih županija ${ }^{85}$ te dosadašnja iskustva s decentralizacijom određenih poslova, ${ }^{86}$ pretpostavlja se da će obavljanje prenesenih poslova značajno varirati među županijama zbog čega će građani različitih županija biti u različitom položaju. Moguće je da će neke županije kad im se za to stvori prilika, kao i neke češke regije, iskoristiti preuzimanje poslova za nova zapošljavanja što je bio slučaj i s nekim hrvatskim gradovima tijekom prijašnjih decentralizacijskih mjera. ${ }^{87}$

Za razliku od češkog i njemačkog slučaja, poslovi državne uprave u Hrvatskoj i dalje se obavljaju u okviru istog teritorijalnog radijusa pa se negativni efekti smanjenja ekonomičnosti i pada specijalizacije te otežanog državnog nadzora uvjetovani spuštanjem poslova na niže teritorijalne razine ne bi trebali realizirati. Gotovo svi poslovi koji su preneseni županijama provedbenog su karaktera i vrlo su detaljno regulirani državnim propisima. ${ }^{88}$ Može se pretpostaviti da njihov prijenos županijama neće dovesti do demokratizacije u njihovu obavljanju, već da će ojačati upravnu ulogu županija i osnažiti položaja župana koji kontrolira županijski upravni aparat u odnosu na županijsku skupštinu. Mogućnost interferencije župana u rješavanje pojedinačnih upravnih stvari moglo bi ugroziti zakonitost i kvalitetu upravnog odlučivanja u prenesenim poslovima.

84 Vidi Jasmina Džinić i Romea Manojlović, 'Evaluating the Impact of Decentralisation on Local Public Management Modernisation in Croatia' in Ivan Koprić, Hellmut Wollmann and Gérard Marcou (eds), Evaluating Reforms of Local Public and Social Services: More Evidence for Better Results (Palgrave Macmillan 2018) 261-78.

85 Vidi Vedran Đulabić, 'Harmonizacija regionalne samouprave u Europi i regionalno pitanje u Hrvatskoj' u Ivan Koprić (ed.) Europeizacija hrvatske lokalne samouprave (Institut za javnu upravu 2018) 447-70.

86 Istraživanje decentralizacije socijalnih usluga pokazalo je izrazite razlike u uslugama različitih županija što vodi ozbiljnoj socijalnoj nejednakosti među hrvatskim građanima, vidi Zdenko Babić, 'Decentralizacija socijalne skrbi i socijalne nejednakosti: slučaj Hrvatske' (2018) 25(1) Revija za socijalnu politiku 25-47.

87 Gordana Marčetić i Iva Lopižić, ‘Utjecaj procesa decentralizacije na personalni kapacitet hrvatske lokalne i područne (regionalne) samouprave' (2017) 17(3) Hrvatska i komparativna javna uprava 418-419. 
Obavljanje poslova u prenesenom djelokrugu trebalo bi ojačati horizontalnu integraciju unutar županija i potaknuti cjelovitiji pristup obavljanju javnih poslova, osobito u županijama koje su primijenile integrirani ili mješoviti model organizacije obavljanja prenesenih poslova. $S$ druge strane, moguće je da će integracija samoupravnih i prenesenih poslova u istim upravnim odjelima dovesti do problema razlikovanja samoupravnih i prenesenih poslova, zamućivanja odgovornosti za obavljanje poslova te problema osiguranja efektivnog nadzora državne vlasti nad obavljanjem poslova.

\section{ZAKLJUČAK}

U radu su prikazane karakteristike prenesenog djelokruga kao modela organizacije obavljanja poslova državne uprave u teritorijalnim jedinicama i procesa upravne decentralizacije kojim nastaje preneseni djelokrug lokalnih jedinica. Uz pregled znanstvene literature o efektima koje provođenje upravne decentralizacije i širenje prenesenog djelokruga imaju na razvoj lokalne samouprave i obavljanje prenesenih poslova, prikazana su iskustva Češke i Njemačke s primjenom prenesenog djelokruga. Komparativni pregled omogućio je da se utvrde pozitivni i negativni učinci provođenja upravne decentralizacije u ovim zemljama te ukazao kako stvarni učinci decentralizacije ovise o kontekstu u kojem se decentralizacija provodi. Uz kapacitet lokalnih jedinica, kao bitni faktori koji utječu na učinke decentralizacije pokazali su se karakteristike upravljanja decentralizacijom, upravna tradicija i primijenjeni model lokalne samouprave, vrsta prenesenih poslova i teritorijalna razina na koju se poslovi prenose te vremenski odmak od provođenja decentralizacije.

Na temelju pregleda znanstvene literature i komparativnih iskustava, formulirane su pretpostavke o mogućim učincima upravne decentralizacije na institucionalni razvoj županija i obavljanje prenesenih poslova. U odnosu na institucionalni razvoj županija, pretpostavlja se da će obavljanje poslova državne uprave u režimu prenesenog djelokruga ojačati položaj županija u hrvatskom upravno-političkom sustavu, ulogu župana u odnosu na županijsku skupštinu, upravnu ulogu županija i multifunkcionalno naličje županija. U odnosu na obavljanje prenesenih poslova, predviđaju se veća horizontalna integracija unutar županija i integriraniji pristup obavljanju javnih poslova, veća dostupnost usluga građanima i veća neujednačenost usluga među različitim županijama, dok se ne očekuju veće promjene u pogledu demokratizacije i ekonomičnosti obavljanja poslova. Pretpostavlja se i kako bi neprikladno osmišljeno i provedeno ukidanje ureda državne uprave, neprikladan način financiranja i mogućnost političke interferencije u rješavanje u pojedinačnim slučajevima mogli negativno utjecati na efektivnost i kvalitetu obavljanja prenesenih poslova. Moguće je da će prijenos poslova potaknuti modernizaciju upravljanja županijama, ali i to da će neke županije prijenos poslova iskoristiti za nova zapošljavanja.

Teorijski utemeljene pretpostavke o učincima prenesenog djelokruga odgovaraju predviđanjima relevantnih aktera o učincima ukidanja ureda državne uprave istraženim u prethodnoj evaluaciji ukidanja ureda. ${ }^{89}$ Svakako, pretpostavke o učincima primjene prenesenog djelokruga u hrvatskim županijama trebaju se ispitati u budućim znanstvenim istraživanjima i evaluacijskim studijama. 


\section{BIBLIOGRAFIJA}

1. Babić Z, 'Decentralizacija socijalne skrbi i socijalne nejednakosti: slučaj Hrvatske' (2018) 25(1) Revija za socijalnu politiku 25

2. Banner G, 'Local Government: A Strategic Resource in German Public Management Reform' in Vincent Hoffmann-Martinot and Hellmut Wollmann (eds), State and Local Government Reforms in France and Germany: Divergence and Convergence (VS Verlag für Sozialwissenschaften 2006) 125-44

3. Bryson PJ, '"State administration" vs. self-government in the Slovak and Czech Republic' (2008) 41(3) Communist and Post-Communist Studies 339

4. Džinić J and Manojlović R, 'Evaluating the Impact of Decentralisation on Local Public Management Modernisation in Croatia' in Ivan Koprić, Hellmut Wollmann and Gérard Marcou (eds), Evaluating Reforms of Local Public and Social Services: More Evidence for Better Results (Palgrave Macmillan 2018) 261-78

5. Đulabić V, 'Harmonizacija regionalne samouprave u Europi i regionalno pitanje u Hrvatskoj' u Ivan Koprić (ed.) Europeizacija hrvatske lokalne samouprave (Institut za javnu upravu 2018) 447-70

6. Ebinger F and Richter P, 'Decentralizing for performance? A quantitative assessment of functional reforms in the German Lander' (2016) 82(2) International Review of Administrative Science 291

7. Ebinger F, Grohs S and Reiter R, 'The Performance of Decentralization Strategies Compared: An Assessment of Decentralization Strategies and their Impact on Local Government Performance in Germany, France and England' (2011) 37(5) Local Government Studies 553

8. Fandel P and others, 'Decentralization Policies in Public Administration in Slovakia and Czech Republic, and Their Impact on Building Offices' Scale Efficiency' (2019) 9(4) Administrative Sciences 1

9. Hemmings P, 'Improving Public-spending Efficiency in Czech Regions and Municipalities' (2006) OECD Economics Department Working Papers, No 499 <https://doi.org/10.1787/884741503537> pristupljeno 2. studenog 2021.

10. Hladík J and Kopecký V, Public Administration Reform in the Czech Republic: Research Paper 3/2013 (Association for International Affairs 2013) <https://www.amo.cz/wp-content/ uploads/2015/11/ amocz-RP-2013-3.pdf> pristupljeno 2. studenog 2021.

11. Illner M, 'Territorial Decentralization: A Stumbling Block of Democratic Reforms in EastCentral Europe?' (1997) 117 Polish Sociological Review 23

12. Koprić I i drugi, Upravna znanost: javna uprava u suvremenom europskom kontekstu (Pravni fakultet i Studijski centar za javnu upravu i javne financije 2014)

13. Koprić I, Lokalna samouprava - nacrt skripta za studij javne uprave (Društveno veleučilište u Zagrebu 2005)

14. Koprić I, 'Lokalni poslovi hrvatskih županija u svjetlu različitih europskih tradicija' u Eugen Pusić i drugi (ed), Hrestomatija upravne znanosti, vol 2 (Pravni fakultet u Zagrebu 1998)

15. Koprić I, 'Upravljanje decentralizacijom kao nov pristup razvoju sustava lokalne samouprave' (2008) 8(1) Hrvatska javna uprava 95

16. Kuhlmann S and Wollmann H, 'The Evaluation of Institutional Reforms at Sub-national Government Levels: A Still Neglected Research Agenda' (2011) 37(5) Local Government Studies 479

17. Kuhlmann $S$ and Wayenberg E, 'Institutional Impact Assessment in Multi-Level Systems: Conceptualizing Decentralization Effects from a Comparative Perspective' (2016) 82(2) International Review of Administrative Sciences 233

18. Kuhlmann S and Wollmann $\mathrm{H}$, Introduction to Comparative Public Administration: Administrative Systems and Reforms in Europe (Edward Elgar 2019) 
19. Kuhlmann S, 'Administrative Reforms in Intergovernmental Setting: Impacts on MultiLevel Governance from a Comparative Perspective' in Edoard Ongaro (ed), Multi-Level Governance: The Missing Linkages (Emerald Group Publishing Limited 2015) 183-215

20. Lalić Novak G, 'Komparativna metoda u proučavanju javne uprave: potencijali i problemi' (2015) 15(1) Hrvatska i komparativna javna uprava 9

21. Lopižić I and Manojlović Toman R, 'Prethodna evaluacija ukidanja ureda državne uprave u županijama' (2019) 69(5-6) Zbornik Pravnog fakulteta u Zagrebu 835

22. Lopižić I, 'Modeli dekoncentriranog obavljanja poslova državne uprave u postsocijalističkim zemljama' (2017) 17(1) Hrvatska i komparativna javna uprava 81

23. Lopižić I, 'Uloga ureda državne uprave u hrvatskome upravno-političkom sustavu' (2020) 20(3) Hrvatska i komparativna javna uprava 549

24. Manojlović R, 'Javna uprava i politički sustav Savezne Republike Njemačke: modernizacija kroz očuvanje tradicije' (2015) 15(1) Hrvatska i komparativna javna uprava 141

25. Marčetić G and Lopižić I, 'Utjecaj procesa decentralizacije na personalni kapacitet hrvatske lokalne i područne (regionalne) samouprave' (2017) 17(3) Hrvatska i komparativna javna uprava 407

26. Ministry of Interior, Public Administration in Czech Republic (Ministry of Interior 2004)

27. Ministry of Interior, Public Administration in Czech Republic (Ministry of Interior 2018)

28. Pollit $C$, 'Decentralization: A Central Concept in Contemporary Public Management' in Ewan Ferlie, Laurence E Lynn and Christopher Pollitt (eds), The Oxford Handbook of Public Management (OUP 2008) 371-97

29. Pomahač R, 'Local Government in the Czech Republic: History, Current Position, Prospective Evolution' in Carlo Panara and Michael R Varney (eds), Local Government in Europe: The 'Fourth Level' in the EU Multi-Layered System of Governance (Routledge 2013) 52-72

30. Půček M and Ochrana F, 'Theory and Practice of Public Sector Savings: The Case of Czech Regions' (2014) 10(2) Transylvanian Review of Administrative Sciences 203

31. Ramljak M, 'Centralna i lokalna uprava u razvoju' u Eugen Pusić i drugi (eds), Hrestomatija upravne znanosti, vol 2 (Pravni fakultet u Zagrebu 1998)

32. Reiter $\mathrm{R}$ and others, 'Impacts of Decentralization: The French Experience in a Comparative Perspective' (2010) 8(2) French Politics 166

33. Richter P and Kuhlmann S, 'Bessere Leistung mit weniger Ressourcen?: Auswirkungen der Dezentralisierung am Beispiel der Versorgungsverwaltung in Baden-Württemberg' (2010) 3(2) DMS - der moderne staat: Zeitschrift für Public Policy, Recht und Management 393-412

34. Sauer A, The System of Local Self-Governments in Poland: Research Paper 6/2013 (Association for International Affairs 2013) <https:/www.amo.cz/wp-content/uploads/2015/11/amocz-RP-2013-6. pdf> pristupljeno 2. studenog 2021.

35. Špaček D and Dvořáková P, 'Impact of Economic Crisis on Municipal Budgets in the Czech Republic' (2011) 14(1) European Research Studies 29

36. Špaček D and Nemec J, Public Administration Characteristics and Performance in EU 28: The Czech Republic (Publications Office of the European Union 2018)

37. Špaček D, 'Trends of E-government in Czech Municipal and Regional Self-Government?' (2012) 12(1) Review of Economic Perpectives 42

38. Štastná L and Gregor M, 'Local Government Efficiency: Evidence from Czech Municipalities' (2011) IES Working Paper 14/2011 <https://papers.ssrn.com/sol3/papers.cfm?abstract_id= 1978730> pristupljeno 2. studenog 2021. 
39. Voldanova J, 'From Comparing to Quality Improvement: Benchmarking and Bench-Learning in the Czech Local Government' (16th NISPAcee Annual Conference, May 2008)

40. Wollmann H, Comparing Local Government Reforms in England, Sweden, France and Germany: Between Continuity and Change, Divergence And Convergence (Wüstenrot Stiftung 2008)

41. Wollmann H, 'Institution Building and Decentralization in Formerly Socialist Countries: The Cases of Poland, Hungary, and East Germany' (1997) 15(4) Environment and Planning C: Politics and Space 463

42. Wollmann H, 'Reforming Local Leadership and Local Democracy: The Cases of England, Sweden, Germany and France in Comparative Perspective' (2008) 34(2) Local Government Studies 279

\section{PROPISI I DOKUMENTI}

1. Ministarstvo uprave, Strateški plan Ministarstva uprave za razdoblje 2019. - 2021. godine (Ministarstvo uprave, 28 ožujka 2018) (HR)

2. Zakon o izvršavanju proračuna Republike Hrvatske za 2020. godinu (NN 117/2019, 32/2020, $58 / 2020,124 / 2020)(H R)$

3. Zakon o sustavu državne uprave (NN 69/2019) (HR)

\section{MREŽNI IZVORI}

1. - - 'Okresní úřady - co bude dál?' Deník (7. kolovoza 2000) <http://www.dvs.cz/clanek. asp?id=59508> pristupljeno 2. studenog 2021.

2. Koprić I, 'Lokalna samouprava u razvoju: vrijednosti i uloge' (Academia.edu, 2015) <https://www. academia.edu/21588077/ Uloge_lokalne_samouprave> pristupljeno 2. studenog 2021.

3. Langšádlová H, 'Náklady na výkon přenesené působnosti' Deník (Prague, 9 January 2004) <http:// denik.obce.cz/clanek.asp?id=5780899> pristupljeno 2. studenog 2021.

4. Ministerstvo vnitra České republiky, 'Analýza aktuálniho stavu veřejné správy' (Ministerstvo vnitra, 14. prosinca 2011) 〈https://www.mvcr.cz/clanek/analyza-aktualniho-stavu-verejne-spravy.aspx> pristupljeno 2. studenog 2021.

5. Špaček D and Neshybová J, «Brief History and Current Trends of Public Administration Reform in the Czech Republic> (ResearchGate, 2010) <https://www.researchgate.net/publication/228448910_ Brief_history_and_current_trends_of_public_administration_reform_in_the_Czech_Republic> pristupljeno 2. studenog 2021. 
Iva Lopižić*

\section{DELEGATED SCOPE OF COMPETENCE IN LOCAL GOVERNMENT: THEORETICAL CONSIDERATIONS AND COMPARATIVE EXPERIENCES}

\section{Summary}

After the abolition of the county administrative offices in January 2020, the tasks performed by the county administrative offices as first-instance state administration bodies were delegated to the counties, as the second level self-government units in Croatia. By this organizational change, the model of deconcentrated performance of state administration tasks was replaced by the model of administrative decentralization. In this context, the paper presents the features of the delegated scope of competence as an organizational performance model of state administration tasks in territorial units and administrative decentralization with a delegated scope of competence as an institutional result. The review of the scholarly literature on the delegated scope of competence and the effects of administrative decentralization is supported by a comparative review of the delegated scope of competence in the Czech and German local self-government. Based on theoretical considerations and comparative practices, the paper discusses the possible effects of the application of the delegated scope of competence in Croatian counties on their institutional development and performance of the delegated tasks.

Keywords: delegated scope of competence, administrative decentralization, effects of administrative decentralization, Czech and German local government, county administrative offices' abolition, Croatian counties.

\section{(c) (1) (9)}

This work is licensed under a Creative Commons

Attribution-NonCommercial 4.0 International License.

Iva Lopižić, PhD, Postdoctoral Fellow, Faculty of Law, University of Zagreb, Trg Republike Hrvatske 14, 10000 Zagreb, Republic of Croatia. E-mail address: iva.lopizic@pravo.hr. ORCID: https://orcid.org/0000-0002-1157-0602. 
